\title{
Methodological approaches to agrobacterium-mediated transformation of buckwheat (Fagopyrum esculentum Moench)
}

Ilina E.L., Kiryushkin A.S., Guseva E.D., Demchenko K.N.

Komarov Botanical Institute, Russian Academy of Sciences, Saint Petersburg, Russia

\author{
E-mail: eilina@binran.ru
}

\begin{abstract}
Key message. The method of Agrobacterium rhizogenes-mediated transformation of buckwheat has been established; composite plants have been obtained. The distribution of the cellular response to auxin by reporter proteins with different maturation times coincides.
\end{abstract}

Keywords: common buckwheat, agrobacterium-mediated transformation, Agrobacterium rhizogenes, composite plants, auxin One of the rapid approaches for studying the hormonal and molecular mechanisms of plant development is to obtain "composite plants". The regulatory interactions between the root system and shoot are preserved in composite plants, while the transgenic roots carry the T-DNA insert of the vector transformed into the cells of the Agrobacterium rhizogenes strain. The buckwheat is an important crop in which, like in Cucurbits, lateral roots are initiated in the apical meristem of the parental root [Ilina et al., 2018]. Methods of A. rhizogenes-mediated transformation of buckwheat are described that lead to the establishment of hairy root cultures, but there are no reports on development of the buckwheat composite plants.

The aim of this study was to establish the method for development of buckwheat (Fagopyrum esculentum Moench) composite plants.

The agrobacterium-mediated transformation technique of Cucurbits [Ilina et al., 2012] has been adapted for buckwheat. Hulled seeds without heat treatment of the "Ballada" buckwheat c.v. were surface sterilized. The wounded bases of the hypocotyls of 4-day-old seedlings were inoculated with A. rhizogenes strain R1000, which is virulent for Fagopyrum tataricum [Thwe et al., 2016]. Agrobacterial cells harboured vectors 242 pKGW-DR5::mNeonGreen-H2B or 242 pKGWDR5::mRuby3-H2B for studying the distribution of the cellular response to auxin. Both vectors contained one of the reporter genes, mNeonGreen or mRuby3, under the control of auxin-sensitive DR5 promoter; as well as pAtUBQ10::DsRED cassette for screening of transgenic roots. Proteins encoded by reporter genes differ in maturation time: mNeonGreen 10-30 min, mRuby $136 \mathrm{~min}$. The presence of target genes insertion in transgenic roots was confirmed by PCR.

Composite plants of buckwheat were obtained. The spatial distribution of the cellular response to auxin was analyzed in transgenic roots. The tissue pattern of response to auxin coincided with that shown for Cucurbitaceae plants: maxima of response to auxin were localized in the region of the initial cells of the cell files, as well as in developing lateral roots primordia. The pattern of cellular response to auxin by $\mathrm{mNeonGreen}$ and mRuby3 reporter proteins with different maturation times did not differ. The research was supported by the RFBR grant 20-016-00233-a.

\section{Методические подходы к агробактериальной трансформации гречихи посевной (Fagopyrum esculentum Moench)}

Ильина Е.Л., Кирюшкин А.С., Гусева Е.Д., Демченко К.Н.

Ботанический институт им. В.Л. Комарова РАН, Санкт-Петербург, Россия

\begin{abstract}
Аннотация. Адаптирована методика агробактериальной трансформации (А. rhizogenеs) гречихи посевной, получены композитные растения. Распределение клеточного ответа на ауксин по белкам-репортерам с разным временем созревания совпадает.
\end{abstract}

Ключевые слова: гречиха посевная, агробактериальная трансформация, Agrobacterium rhizogenеs, композитные растения, ауксин

Одним из экспресс-подходов для изучения гормональных и молекулярно-генетических механизмов развития растений является получение «композитных растений», которые сохраняют регуляторные связи между корневой системой и побегом, при этом трансгенные корни несут вставку Т-ДНК вектора, введённого в клетки штамма Agrobacterium rhizogenes. Гречиха посевная является важной сельскохозяйственной культурой, у которой, как и у Тыквенных, боковые корни закладываются в апикальной меристеме родительского корня [Ilina et al., 2018]. Для гречихи описаны методики трансформации A. rhizogenes, приводящие к образованию культуры бородатых корней, но отсутствуют данные о получении композитных растений.

Целью данной работы было адаптировать методику получения композитных растений для гречихи посевной (Fagopyrum esculentum Moench).

Методика агробактериальной трансформации Тыквенных [Ilina et al., 2012] была адаптирована для гречихи. Неочищенные семена гречихи сорта «Баллада» без тепловой обработки подвергали поверхностной стерилизации. Основание гипокотиля 4-х дневных проростков инокулировали штаммом R1000 A. rhizogenes, который вирулентен для гречихи татарской [Тhwе еt al., 2016]. Клетки агробактерий содержали вектор для изучения распределения клеточного ответа на ayксин 242 pKGW-DR5::mNeonGreen-H2B или 242 pKGW-DR5::mRuby3-H2B. Оба вектора содержали один из репортерных генов - $\mathrm{mNeonGreen} \mathrm{или} \mathrm{mRuby3} \mathrm{-} \mathrm{под} \mathrm{контролем}$ ауксин-чувствительного промотора DR5, а также скрининговую кассету pAtUBQ10::DsRED для отбора трансгенных корней. Белки, кодируемые репортерными генами, отличаются по времени созревания: mNeonGreen 10-30 мин, mRuby 136 мин. Наличие вставки целевых генов в трансгенных корнях было подтверждено методом ПЦР.

Были получены композитные растения гречихи. В трансгенных корнях проанализировано пространственное распределение клеточного ответа на ауксин. Тканевой паттерн ответа на ауксин совпадал с тем, который был показан для растений семейства Тыквенные: максимумы ответа на ауксин были локализованы в области инициалей рядов клеток, а также в развивающихся примордиях боковых корней. Паттерн клеточного ответа на ауксин по репортерным белкам mNeonGreen и mRuby3 с разным временем созревания не отличался.

Исследования поддержаны грантом РФФИ 20-016-00233-а. 